Research Article

\title{
The Impact of Employee Stock Ownership Plan on the Cost of Equity Capital: Evidence from China
}

\author{
Fu Cheng $\mathbb{D}^{1}$ and Shanshan Ji $\mathbb{D}^{2}$ \\ ${ }^{1}$ School of Business Administration, Northeastern University, Shenyang 110167, China \\ ${ }^{2}$ School of Economics and Management, Harbin Institute of Technology, Harbin 150001, China \\ Correspondence should be addressed to Fu Cheng; chengfu@mail.neu.edu.cn
}

Received 25 September 2021; Revised 14 November 2021; Accepted 16 November 2021; Published 29 November 2021

Academic Editor: Baogui Xin

Copyright (c) $2021 \mathrm{Fu}$ Cheng and Shanshan Ji. This is an open access article distributed under the Creative Commons Attribution License, which permits unrestricted use, distribution, and reproduction in any medium, provided the original work is properly cited.

\begin{abstract}
Due to the immaturity of bond market and the defects of internal governance structure, Chinese-listed companies have a strong preference for equity financing. How to reduce the cost of equity capital is particularly important for Chinese-listed companies. As an equity incentive system, employee stock ownership plan (ESOP) can reduce the agency conflicts among shareholders, executives, and employees to some extent. These reduced conflicts will, in an efficient capital market, be reflected in a lower cost of equity capital. This paper investigates whether the implementation of ESOP in a new era in China affects the cost of equity capital and further explores whether the impact of ESOP on the cost of equity capital is affected by the ownership nature, the firm size, and the contract design of ESOP. The results show that the implementation of ESOP reduces the cost of equity capital of enterprises. Compared with state-owned enterprises and large enterprises, the implementation of ESOP is more likely to reduce the cost of equity capital in non-state-owned enterprises and small enterprises. Furthermore, the reduction effect of ESOP on the cost of equity capital is influenced by the contract design of ESOP. This study not only enriches the literature on the relationship between employee stock ownership and the cost of equity capital but also provides a new idea for listed companies to reduce the cost of equity financing.
\end{abstract}

\section{Introduction}

Cost of equity capital is an ability of enterprises to obtain funds from the capital market, and it is a key factor affecting the efficiency of resource allocation in the capital market [1]. For investors, cost of equity capital is the minimum rate of return required by investors when they invest in stocks. For enterprises, cost of equity capital is the price paid by enterprises to obtain funds through issuing common shares. Cost of equity capital is not only an important basis for enterprises to choose capital sources, design financing schemes, and determine financing methods but also a main reference index for enterprises to judge the feasibility of investment and decide whether to invest. It plays an important role in enterprises' financial decision-making and value evaluation [2]. Due to the imperfect bond market and the defects of corporate governance structure, Chinese-listed companies have a strong preference for equity financing, and there is a typical abnormal order financing phenomenon [3-5]. Therefore, under the unique institutional background of China, it is of great theoretical significance and practical value to study the influencing factors of the cost of equity capital and how to effectively reduce the cost of equity capital of enterprises.

Employee stock ownership plan (ESOP) is an innovative equity incentive method, which aims to enable employees and owners to share the company's residual earnings and bear the company's risks by giving employees the stock of their own company, so as to realize the effective unification of the interest of employees and owners. The earliest advocate of ESOP was Louis Kelso, who proposed the Two Factor Theory in the mid-1950s and designed ESOP under the guidance of this theory. Subsequently, ESOP was quickly applied and gradually improved in practice and was widely 
implemented in the capital market of Western countries. However, due to China's special institutional background and regulatory environment, the development of ESOP in China lags far behind that of western developed countries. Until June 20, 2014, the China Securities Regulatory Commission (CSRC) issued the Guiding Opinions on the Pilot Implementation of Employee Stock Ownership Plan by Listed Companies (hereinafter referred to as Guiding Opinions), once again set off China's listed companies implementation of ESOPs, ESOP also gradually become the staff long-term incentive and the reform of state-owned equity of listed companies.

Throughout the existing literature on ESOP, scholars focus on the implementation motivation of ESOP [6-8], the shareholder wealth effects of ESOP [9-11], and the impact of ESOP on enterprise performance [12-14], but little attention is paid to the impact of ESOP on the cost of equity capital. Previous studies show that the cost of equity capital is mainly affected by the enterprise's own operating risk and information environment [15-17]. By implementing ESOPs, enterprises can not only reduce corporate risks by transferring part of the risks borne by external shareholders to internal employees [18] but also reduce information asymmetry between external shareholders and internal employees by improving the company's information disclosure environment [19], which can both affect the cost of equity capital of enterprises. Therefore, based on the background of equity financing preference of Chinese-listed companies, this paper discusses the impact of ESOP in the new period (ESOP in China means ESOPs implemented after the issuance of the Guiding Opinions) in China on the cost of equity capital of enterprises.

Firstly, we test whether the implementation of ESOP affects the cost of equity capital and whether the effect varies with the ownership nature and the size of enterprises. Taking companies implementing ESOPs as the treatment group and companies not implementing ESOPs as the control group, we find that the implementation of ESOP is negatively correlated with the cost of equity capital, indicating that the implementation of ESOP reduces the cost of equity capital of enterprises. We further find that the reducing effect of ESOP implementation on the cost of equity capital exists in nonstate-owned enterprises and small enterprises, but does not exist in state-owned enterprises and large enterprises, indicating that compared with state-owned-enterprises and large enterprises, it is more suitable for non-state-ownedenterprises and small enterprises to implement ESOPs.

Secondly, considering the previous findings that the effects of ESOP on firm performance and shareholder wealth are both affected by the contract design of ESOP [20, 21], we further examine whether the contract elements of ESOP affect the cost of equity capital. According to the Guiding Opinions, the contact elements of ESOP usually include funding sources (e.g., employee's own funds, withdraw incentive funds from firm's net income, borrowings from the control shareholders or the actual controller, and the thirdparty financing), stock sources (e.g., repurchase the company's shares, purchase the company's shares on the secondary market, gift shares from major shareholders, and subscribe for nonpublic offering shares), executive subscription ratio (i.e., the proportion of ESOP shares subscribed by executives), and lockup period (i.e., the minimum holding period of ESOP). Taking companies implementing ESOPs as the study sample, we find that ESOPs funded by employee's own funds and ESOPs having higher executive subscription ratios or longer lockup periods are negatively correlated with the cost of equity capital, while ESOPs implemented by purchasing shares on the secondary market are positively correlated with the cost of equity capital. These results suggest that the effect of ESOP on the cost of equity is determined to some extent by the contract design of ESOP.

This study enriches the literature on the relationship between employee stock ownership and the cost of equity capital. Although several literature studies have focused on the relationship between employee stock ownership and the cost of equity capital, no consistent conclusions have been drawn. Based on Japanese electronics industry companies, Barney [22] found that employee stock ownership reduces the conflict of interest between external shareholders and internal employees, thus reducing the cost of equity capital of enterprises. However, Aubert et al. [23] found no significant relationship between employee stock ownership and the cost of equity capital based on French-listed companies. Based on US-listed companies, Campa and Kern [24] found that only a low level of employee stock ownership can reduce the cost of equity capital. Our study shows that, in Chineselisted companies that prefer equity financing, the implementation of ESOP can significantly reduce the cost of equity capital, and the reduction effect varies with firm's ownership nature, firm size, and the contract design of ESOP. These conclusions not only provide empirical evidence from emerging markets for understanding the relationship between employee stock ownership and the cost of equity capital but also provide new insights for capital market participants to understand the capital market consequences of ESOP. In addition, this study also provides a new way for listed companies to reduce the cost of equity financing, that is, corporate management can reduce the cost of equity capital by reasonably designing and implementing the ESOPs.

\section{Institutional Background and Literature Review}

2.1. Institutional Background. The ESOP was first proposed by Louis Kelso, an American economist, in 1956. Kelso sees an ESOP as a financing tool that can do both things by providing the money a business needs to grow and by turning employees into business owners. At present, ESOPs in the United States have been very mature, from the macroenvironment to specific laws and regulations, including third-party trusteeship institutions, entry and exit mechanism, relevant laws and regulations, and tax preferential policies. Mature and perfect supporting systems have provided a good development environment for the longterm development of ESOPs in the United States. The success of ESOPs in the United States has also been recognized by other countries. The United Kingdom, Germany, 
Japan, France, and other countries have also established and developed their own ESOPs.

China's ESOPs originated from the internal employee stock system in the 1980s. At that time, China was in the pilot period of transforming enterprise operation mechanism and joint-stock system, and a number of small stateowned enterprises and collective enterprises carried out a variety of shareholding attempts. In the 1990s, influenced by foreign ESOPs, bold attempts were made everywhere, and employee stock ownership boomed. However, due to the absence of owners and imperfect system design, the internal employee stock was used by a few people, resulting in serious loss of state-owned assets, and the internal employee stock was suspended several times by the CSRC. It can be seen that China's early ESOPs have experienced many ups and downs in its development from barbaric growth to emergency suspension and then to suspension of issuance.

Until June 20, 2014, CSRC issued the Guiding Opinions and revived the ESOP in listed companies. The Guiding Opinions makes detailed provisions on the participants, sources of stock, sources of funding, lockup periods, and issue pricing of ESOPs implementing in listed companies and standardizes and consolidates relevant approval procedures. It marks a new period for the development of ESOPs in China. Unlike ESOPs in the 1990s, listed companies are allowed to customize ESOPs to their own situation according to the Guiding Opinions without special permission from the CSRC in the new period. Since the issuance of the Guiding Opinions, more and more listed companies have launched ESOPs, and ESOPs in China is blooming again.

2.2. Literature Review. This paper reviews literature on employee stock ownership and corporate ownership. Previous studies have focused on the effects of employee stock ownership on R\&D expenditures [25], corporate risk [18], firm disclosure [19], private loan pricing [26], and stock liquidity [27]. Cheng and Huang [25] provided evidence that employee stock ownership could enable firms to make sizable R\&D expenditures. Bova et al. [18] suggested that nonexecutives not only faced significant incentives to reduce risk when they held stock but they were also able to affect corporate risk. Bova et al. [19] found a positive link between employee ownership and voluntary disclosure when employees had bargaining power. Chen et al. [26] found that a one-standard-deviation increase in employee stock ownership was associated with $1.67 \%$ decrease in loan spreads and one fewer restrictive loan covenant. Jung and Choi [27] corroborated that employee stock ownership was positively associated with stock liquidity. In addition, Quimet and Tate [28] found that following the 2008 Financial Crisis, employees became more likely to exercise options, sell restricted stock, and participate in an Employee Stock Purchase Plan.

In recent years, Chinese researchers pay attention to the effects of ESOP on firm performance [29], employee career development [30], stock price crash risk [31], and corporate innovation [32]. Ren et al. [29] found that ESOP-adopters had higher performance than matched non-ESOP firms both before and after adoption, but the relative performance did not increase after adoption. Xiao et al. [30] suggested that employees' career development benefited when ESOP funds originated from employee compensation and self-raised funds, when the plan's stock came from a source other than the secondary market, and when employees and senior executives held a higher proportion of a firm's total shares. Li et al. [31] provided evidence that an ESOP announcement was significantly and negatively related to a firm's stock price crash risk. Si et al. [32] documented that nonexecutive ESOPs had a significantly positive impact on the number of patents applied by energy companies, and that the positive effect was particularly pronounced in non-state-owned enterprises, companies with higher $\mathrm{R} \& \mathrm{D}$ intensity, and companies with less free-riding.

Except for empirical studies on employee stock ownership, there are several valuable normative researches on corporate ownership. Chen et al. [33] investigated the optimal proportion of employee stock in duopoly markets. They suggested that the enterprise ownership nature had a direct bearing on the optimal proportion of employee stock and determined whether to implement the ESOP and the specific level of the plan, and that the optimal proportion of employee stock was positively correlated with its contribution to enterprise efficiency in most cases. Chen et al. [34] further explored the optimal proportion of employee stocks in state-owned enterprises in China. They found that partial holding, full holding, or nonholding could be optimal, and the optimal proportion depended on the types of rival firms, the efficiency gap in different kinds of shares, and employee behavioral tendencies. Chen et al. [35] studied the optimal international cross-ownership and state-owned shares proportion when domestic state-owned enterprise competes with foreign-funded enterprise in home market or against local enterprise in foreign market under Cournot competition. Their results documented that whether to implement international cross-ownership or not and the proportion of state-owned depended on the implementing subject of cross-ownership, competitive environment, and the efficiencies of state-owned and private capitals.

In sum, there are many studies on employee stock ownership. However, only a few studies focus on the effect of employee stock ownership on the cost of equity capital, and no consistent conclusions have been drawn. Based on Japanese electronics firms, Barney [22] found that employee stock ownership reduced the cost of equity capital. But Aubert et al. [23] found no significant relationship between employee stock ownership and the cost of equity capital based on French-listed companies. Based on all of the S\&P 500 firms, Campa and Kern [24] found weak evidence that employee stock ownership had a favorable impact on the cost of equity capital, that is, employee stock ownership decreased the cost of equity capital only for low levels of employee ownership. Unlike Japan, France, and the United States, listed companies have a high degree of ownership concentration, and a large proportion of them are stateowned enterprises in China. Therefore, previous conclusions drawn from Japanese, French, or the United State firms may not apply to Chinese firms. We investigate the impact of 
ESOP on the cost of equity capital in Chinese listed companies, which can provide new evidence on the association between employee stock ownership and the cost of equity capital from the emerging markets.

\section{Theory Analysis and Hypothesis Development}

\subsection{The Implementation of EOSP and the Cost of Equity Capital}

3.1.1. The Main Effect. As a new type of equity incentive, the implementation of ESOP will form two effects: internal incentive effect and external market effect. First of all, because the incentive object of ESOP includes senior executives and ordinary employees, the implementation of ESOP will have incentive effect on both executives and employees. Generally speaking, as the owner of capital, shareholders enjoy the long-term benefits brought by enterprise assets, while executives and employees can only pay for short-term income through labor, so there may be conflicts of interest among the three parties [36]. By implementing ESOPs, enterprises can effectively unify the interests of shareholders, executives, and employees. For executives, to some extent, shareholding can alleviate the agency conflict between external shareholders and internal executives and urge executives to pay more attention to the long-term development of the company when making decisions. For employees, shareholding will enhance their sense of ownership and belonging to the enterprise and motivate them to work harder, so as to ease the agency conflict between executives and employees. In an efficient capital market, the reduction of agency conflicts within firms will be reflected in the reduction of the cost of equity capital [22]. Therefore, the implementation of ESOP helps to reduce agency conflicts among shareholders, executives, and employees, thus reducing the cost of equity capital of enterprises.

Secondly, since risk and reward are the key factors for investors to weigh when making decisions in the market economy, the external market effects of ESOP implementation can be understood from the perspectives of risk and reward. From the perspective of risk, the implementation of ESOP enables shareholders to transfer part of the company's equity to executives or employees, which can reduce the risk of one dominant share in an enterprise, thus improving the corporate governance structure but may also lead to the expansion of the scope of power of executives. In order to carry out effective checks and balances on executives, enterprises will establish a more standardized supervision mechanism, and the improvement of the internal supervision mechanism will reduce the moral hazard of executives caused by the agency relationship, and shareholders will strengthen the supervision of executives' decision, so as to reduce the operation risk of enterprises. From the perspective of reward, executives and employees are the company's main profit generator in the normal course of business and labor givers, the implementation of ESOP will reflect on both the incentive effect for the improving of the company's performance, so as to improve the future benefits of investors, and investors will reduce the necessary return rate as required [37]. Therefore, the implementation of ESOP can help reduce the moral hazard of executives and the firm's business risk, and thus reduce the cost of equity capital of enterprises.

This paper summarizes the theoretical analysis process above as shown in Figure 1. Based on the analysis above, the following hypothesis is proposed:

Hypothesis 1. The implementation of ESOP is negatively correlated with the cost of equity capital.

\subsubsection{The Moderating Effect of Ownership Nature. Due to} the uniqueness of the economic market environment, Chinese-listed companies can be divided into state-owned enterprises and non-state-owned enterprises according to the type of actual controller, and there are large differences in the external policy regulation and the internal governance structure in the two types of enterprises, causing the effect of ESOP on the cost of equity capital may be different in the two types of enterprises [38].

Compared with non-state-owned enterprises, stateowned enterprises have the following characteristics that may weaken the incentive effect of ESOP. First, state-owned enterprises have strict rules on the compensation of both executives and employees, and these rules will undermine the incentive effect of EOSP on executives and employees. Secondly, the unique resource allocation and promotion mechanism of state-owned enterprises makes senior executives tend to engage in opportunistic behavior of seeking political promotion, and leads to the free ride behavior of more employees, which leads to the increase of the cost of equity capital of state-owned enterprises. In addition, the absence of owners in state-owned enterprises will reduce the enthusiasm of senior executives to create value for the enterprise and increase the supervision cost of external shareholders [39]. When the implementation of ESOP provides insufficient incentives to executives and employees, the existing shareholders and potential investors of stateowned enterprises will face more uncertain risks, thus they will increase the expected return on investment, resulting in the increase of the cost of equity capital of the company.

Unlike state-owned enterprises, non-state-owned enterprises have a more open competitive environment and are less regulated by government policies, and their wage and performance management systems are more market-oriented. Since non-state-owned enterprises need to bear their own risks and profits and losses, their internal competition mechanisms will make the competition among employees more intense, thus reducing the possibility of free-riding behavior of employees. In addition, employees in non-stateowned enterprises are more open and can accept higher pay gaps due to performance differences, and non-state-owned enterprises have better internal control systems, more transparent promotion mechanisms, and more decentralized ownership structures. Therefore, the implementation of ESOP in non-state-owned enterprises can effectively alleviate the agency conflict between shareholders and 


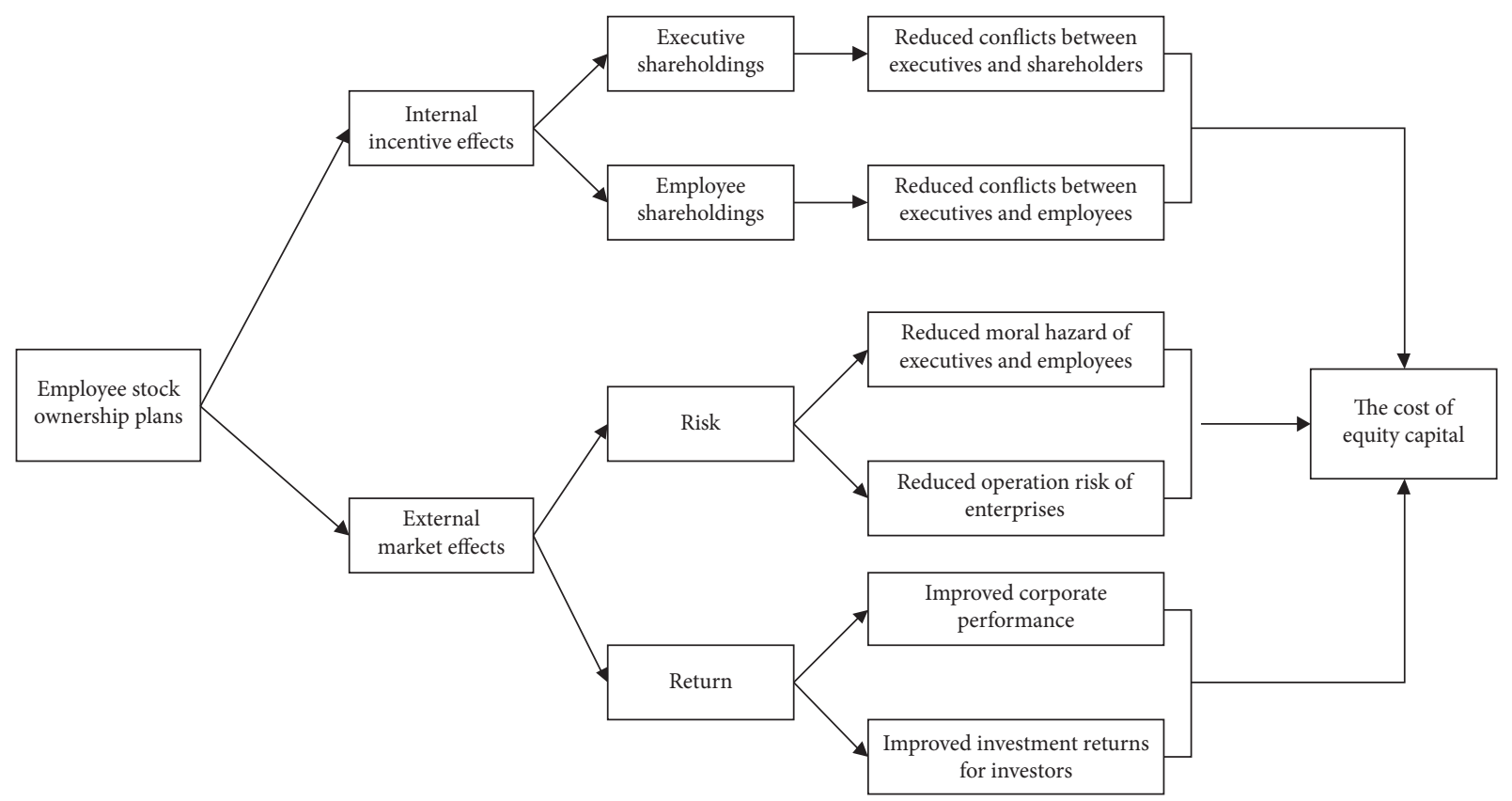

FIgURE 1: The mechanisms of how ESOP affects the cost of equity capital.

executives, as well as between executives and employees, and obtain lower cost of equity funds for enterprises.

Based on the analysis above, the following hypothesis is proposed:

Hypothesis 2. The negative correlation between ESOP implementation and the cost of equity capital exists in nonstate-owned enterprises, but does not exist in state-owned enterprises.

3.1.3. The Moderating Effect of Firm Size. Because large enterprises and small enterprises have great differences in asset scale, financing constraints and free-riding problems, the impact of ESOP on the cost of equity capital may be different in these two types of enterprises. First of all, it is generally believed that large enterprises or super-large enterprises have tens of billions of assets. Even if the core management personnel or technical backbones hold shares, their shareholding proportion is insignificant in the total amount, which will weaken the enthusiasm of employees to hold shares. Therefore, employee stock ownership plan is usually applied to small enterprises [40].

Secondly, compared with large enterprises, small enterprises have higher degree of financing constrains. Compared with large enterprises, small enterprises generally have higher operational and financial risks. Due to the small asset scale of small enterprises, the initial capital of enterprise operation mainly depends on internal financing, and the external financing capacity is very limited [41]. Therefore, compared with larger enterprises, small enterprises face more serious financing constraints. In other words, the governance effect of ESOP is more likely to be realized in small enterprises with higher financing constraints. Finally, the extent of free-riding is smaller in firms with fewer employees since the overall firm success is more sensitive to the actions of individual workers. In other words, free-riding problems are less severe in small enterprises than in large enterprises. Previous studies have corroborated that the positive effects of ESOP is offset by free-riding problems $[32,42]$. Thus, we expect that the negative effect of ESOP on the cost of equity capital is more pronounced in small enterprises than in large enterprises.

Based on the analysis above, the following hypothesis is proposed:

Hypothesis 3. The negative correlation between ESOP implementation and the cost of equity capital exists in small companies, but does not exist in large companies.

\subsection{The Contract Elements of EOSP and the Cost of Equity Capital}

3.2.1. The Funding Sources of ESOP and the Cost of Equity Capital. According to the Guiding Opinions and the ESOP drafts announced by Chinese listed companies, the ESOP can solve the required funds in the following ways: (i) employee compensation and self-raised funds; (ii) incentive funds drawn by listed companies; (iii) borrowing by the controlling shareholder or the actual controller; (iv) thirdparty financing; and (v) other means permitted by laws and administrative rules. As for the employees, once they hold the stock in the employee stock ownership plan with their own funds, they need to jointly bear the operating risk of the enterprise with the shareholders because the decline of the company's performance will cause the decline of the company's stock price, which will further damage the personal wealth of employees. In order to avoid the loss of their own wealth, employees will be more actively involved in the 
company's business decisions and strive to improve the company's business performance. Employee free-riding behaviors can occur if employees do not participate in ESOP with their own money, so that they can enjoy the additional benefits of the company's rising stock price without the risk of losing their wealth. Therefore, when an enterprise implements ESOP with employee compensation and self-raised funds, the interests of employees and shareholders will be more closely linked, which is conducive to encouraging the release of human capital and reducing the cost of equity capital of the enterprise.

Based on the analysis above, the following hypothesis is proposed:

Hypothesis 4. Compared with other sources of funding, companies implementing ESOPs funded by employee compensation and self-raised funds have lower cost of equity capital.

\subsubsection{The Stock Sources of ESOP and the Cost of Equity} Capital. According to the Guiding Opinions, the ESOP can solve the stock sources by the following ways: (i) repurchasing companies' own shares; (ii) buying company stocks in the secondary market; (iii) subscribing for nonpublic offering shares; (iv) voluntary gifted by shareholders; and (v) other means permitted by laws and administrative regulations. Generally speaking, the cost of purchasing the underlying stock in the ESOP through the secondary market is the highest and the potential for future stock price growth is the lowest compared with the other stock sources (e.g. voluntary gifted by shareholders, repurchase of the company's own shares, or subscription of nonpublic offering shares). Therefore, compared with other stock sources, ESOPs implemented through secondary market purchases has a weaker incentive effect on employees, thus increasing the cost of equity capital of enterprises.

Based on the analysis above, the following hypothesis is proposed:

Hypothesis 5. Compared with other sources of stock, companies implementing ESOPs by buying shares on the secondary markets have higher cost of equity capital.

\subsubsection{The Executive Subscription Ratio in ESOP and the Cost} of Equity Capital. According to the Guiding Opinions, the incentive objects of ESOP include executives and employees, so both senior executives and ordinary employees are the participants of ESOP. Although the employee is the main incentive object in the new era of China's ESOP, in practice, most of ESOPs involve senior executives, or even some involve only senior executives. When executives subscribe for a large number of shares, the implementation of ESOP can effectively alleviate the agency conflict caused by the separation of the two rights, thus reducing the agency costs between shareholders and executives and also reducing the moral hazard of executives. In addition, based on the signaling theory, the behavior of senior executives subscribing for the company's shares also indicates that the company's internal staffs are full of confidence in the company's future development. The larger the subscription proportion is, the higher the company's growth will be. When investors in the secondary market receive this positive signal, they will lower the required rate of return.

Based on the analysis above, the following hypothesis is proposed:

Hypothesis 6. The higher the subscription ratio of executives in ESOP, the lower the cost of equity capital of the enterprise.

\subsubsection{The Lockup Period of ESOP and the Cost of Equity} Capital. The lockup period of ESOP refers to the period during which the underlying stock in the ESOP cannot be sold. Only after the lockup period expires, the administrator of the ESOP can sell the stock at his choice. According to the Guiding Opinions, the lockup period of each ESOP shall not be less than 12 months. If the ESOP is implemented by subscribing for non-public offering shares, the lockup period shall not be less than 36 months, starting from the time when the listed company announces the transfer of the underlying stocks to the current shareholding plan. The design of lockup period effectively binds the interests of ESOP participants with those of the company. The longer the lockup period, the longer the interests of shareholding employees are bound with the interests of the company, the higher the enthusiasm of employees during the lockup period, and the maximum effectiveness of human resources can be exerted, thus reducing the cost of equity capital of the enterprise.

Based on the analysis above, the following hypothesis is proposed:

Hypothesis 7. The longer the lockup period of ESOP, the lower the cost of equity capital of the enterprise.

\section{Methodology}

4.1. Data and Sample. In this paper, Chinese A-share listed companies in Shanghai and Shenzhen Stock Exchanges from 2014 to 2018 are selected as the initial sample, and the following screening procedures are carried out: (i) ST and *ST companies are excluded because these companies usually have abnormal financial indicators; (ii) companies in financial or insurance industry are excluded because the financial data of these companies are not comparable with those of companies in other industries; (iii) companies whose cost of equity capital is less than 0 or greater than 1 are excluded; (iv) companies with missing variable data. After screening the procedures above, 3360 companies were obtained, including 492 companies implementing ESOPs and 2868 companies not implementing ESOPs. In addition, in order to eliminate the influence of extreme values on empirical results, all continuous variables are winsorized at the $1 \%$ percentile at both tails of their distributions.

In this paper, the PEG model is used to estimate the cost of equity capital of listed companies. The analyst forecasts of earnings per share data and the actual closing price data at the end of the year are used, among which the analyst 
forecast data comes from CSMAR database and the stock closing price data comes from RESSET database. The data of implementation and contract elements of ESOPs are from Wind database, and other financial data are from CSMAR database.

\subsection{Variables}

4.2.1. Dependent Variables. The dependent variable of this paper is the cost of equity capital (COE). Previous studies have shown that the PEG model is widely recognized by scholars because of its high estimation efficiency and application feasibility [43]. Because PEG model can fully reflect the impact of various risk factors and considering the particularity of China's capital market environment and the availability of data, this paper chooses the PEG model to estimate the cost of equity capital of enterprises. The specific model is as follows:

$$
\mathrm{COE}_{i, 0}=\sqrt{\frac{\mathrm{eps}_{i, 2}-\mathrm{eps}_{i, 1}}{p_{i, 0}}},
$$

where $\mathrm{COE}_{i, 0}$ represents the cost of equity capital of company $i$ in the current year, eps $s_{i, 1}$ represents the analyst forecasts of the company's earnings per share one year later, $\mathrm{eps}_{i, 2}$ represents the analyst forecasts of the company's earnings per share two years later, and $p_{i, 0}$ represents the actual closing price of per share of company $i$ at the end of the year. Considering that, in practice, there are a large number of analysts issuing forecasts on the earnings per share of company $i$ in years of $t+1$ and $t+2$, this paper takes the mean of these analyst forecasts as the forecast value of the company's future earnings per share.

4.2.2. Independent Variables. The independent variables of this paper include the implementation of ESOP and the contract elements of ESOP. A binary dummy variable ESOP_dummy is designed to describe the implementation of ESOP: if the company releases the draft of ESOP and completes the purchase of the underlying stock within the sample period, the value is 1 ; otherwise, the value is 0 . The contract elements of ESOP considered in this paper include: (i) stock sources (ESOP_stock), takes the value of 1 when the stocks of ESOP is purchased on the secondary market, or 0 otherwise; (ii) funding sources (ESOP_fund), takes the value of 1 when the capital source of ESOP is employee compensation and self-raised funds or 0 otherwise; (iii) subscription ratio of executives (ESOP_exepurchase), is equal to the proportion of shares purchased by executives in the ESOP; (iv) lockup period (ESOP_lockup) is equal to the minimum shareholding period of the ESOP.

4.2.3. Categorical Variables. In order to examine whether the impact of ESOP implementation on the cost of equity capital varies with the ownership nature and the size of enterprises, this paper designs two categorical variables, including SOE and Large. SOE takes the value of 1 when the company is state-owned or 0 otherwise. Large takes the value of 1 when the size (measured by the natural log of total assets at the end of the year) of the company is above the median value of the full sample or 0 otherwise.

4.2.4. Control Variables. Based on previous literature $[23,24]$, this paper controls the influence of the following factors on the cost of equity capital: (i) firm size (Size), which is equal to the natural logarithm of total assets; (ii) board size (Board), which is equal to the natural logarithm of the number of board members; (iii) asset-liability ratio (Lev), which is equal to the ratio of total liabilities to total assets; (iv) operational risk (Orisk), which is measured by the proportion of long-term assets to total assets; (v) firm growth (Growth), which is measured by the growth rate of operating revenue; (vi) firm profitability (ROA), which is measured by return on total assets; (vii) stock liquidity (Liquidity), which is measured by the annual turnover rate of the company's tradable shares; (viii) ownership concentration (Shr1), which is measured by the shareholding ratio of the largest shareholder; and (ix) industry fixed effects (Industry) and year fixed effects (Year).

4.3. Models. In order to test the impact of ESOP implementation on the cost of equity capital, this paper designs Model (2). First, the regression estimation of Model (2) is made by using the full sample, and then the regression estimations of Model (2) are made by using state-owned enterprise subsample, non-state-owned enterprise subsample, large enterprise subsample and small enterprise subsample respectively. According to Hypothesis 1, Hypothesis 2, and Hypothesis 3, the coefficients of ESOP_dummy are expected to be significantly negative in the full sample, the non-state-owned enterprise subsample and the small enterprise subsample.

$$
\begin{aligned}
\mathrm{COE}= & \alpha_{0}+\alpha_{1} \text { ESOP_dummy }+\alpha_{2} \text { Orisk }+\alpha_{3} \text { Size }+\alpha_{4} \text { Board } \\
& +\alpha_{5} \text { Lev }+\alpha_{6} \text { Growth }+\alpha_{7} \text { ROA }+\alpha_{8} \text { Linquity }+\alpha_{9} \text { Shr } 1+\sum \text { Industry }+\sum \text { Year }+\varepsilon
\end{aligned}
$$

In order to further test the impact of contract elements of ESOP on the cost of equity capital, this paper designs Model (3), Model (4), Model (5), and Model (6), and uses the subsample of companies implementing ESOPs to estimate them. Model (3) is used to test the relationship between the funding source of ESOP and the cost of equity capital. According to Hypothesis 4, the coefficient of ESOP_fund is expected to be significantly negative. 


$$
\begin{aligned}
\mathrm{COE}= & \alpha_{0}+\alpha_{1} \text { ESOP_fund }+\alpha_{2} \text { Orisk }+\alpha_{3} \text { Size }+\alpha_{4} \text { Board } \\
& +\alpha_{5} \text { Lev }+\alpha_{6} \text { Growth }+\alpha_{7} \text { ROA }+\alpha_{8} \text { Linquity }+\alpha_{9} \text { Shr } 1+\sum \text { Industry }+\sum \text { Year }+\varepsilon
\end{aligned}
$$

Model (4) is used to test the relationship between the stock source of ESOP and the cost of equity capital.
According to Hypothesis 5, the coefficient of ESOP_stock is expected to be significantly positive.

$$
\begin{aligned}
\mathrm{COE}= & \alpha_{0}+\alpha_{1} \text { ESOP_stock }+\alpha_{2} \text { Orisk }+\alpha_{3} \text { Size }+\alpha_{4} \text { Board } \\
& +\alpha_{5} \text { Lev }+\alpha_{6} \text { Growth }+\alpha_{7} \text { ROA }+\alpha_{8} \text { Linquity }+\alpha_{9} \text { Shr } 1+\sum \text { Industry }+\sum \text { Year }+\varepsilon .
\end{aligned}
$$

Model (5) is used to test the relationship between executive subscription ratio in ESOP and the cost of equity capital. According to Hypothesis 6, the coefficient of ESOP_exepurchase is expected to be significantly negative.

$$
\begin{aligned}
\text { COE }= & \alpha_{0}+\alpha_{1} \text { ESOP_exepurchase }+\alpha_{2} \text { Orisk }+\alpha_{3} \text { Size }+\alpha_{4} \text { Board } \\
& +\alpha_{5} \text { Lev }+\alpha_{6} \text { Growth }+\alpha_{7} \text { ROA }+\alpha_{8} \text { Linquity }+\alpha_{9} \text { Shr } 1+\sum \text { Industry }+\sum \text { Year }+\varepsilon .
\end{aligned}
$$

Model (6) is used to test the relationship between the lockup period of ESOP and the cost of equity capital.
According to Hypothesis 7, the coefficient of ESOP_lockup is expected to be significantly negative.

$$
\begin{aligned}
\mathrm{COE}= & \alpha_{0}+\alpha_{1} \text { ESOP_lockup }+\alpha_{2} \text { Orisk }+\alpha_{3} \text { Size }+\alpha_{4} \text { Board } \\
& +\alpha_{5} \text { Lev }+\alpha_{6} \text { Growth }+\alpha_{7} \text { ROA }+\alpha_{8} \text { Linquity }+\alpha_{9} \text { Shr } 1+\sum \text { Industry }+\sum \text { Year }+\varepsilon
\end{aligned}
$$

\section{Results}

5.1. Descriptive Analysis. Table 1 reports the descriptive statistics of research variables for the full sample. In terms of dependent variable, the mean, minimum, and maximum values of cost of equity capital (COE) estimated by the PEG model are $0.113,0$, and 0.536 , respectively, indicating that, in China capital market, listed companies need to pay an average of $11.3 \%$ return to investors in order to obtain funds by equity financing, and there is a great gap of equity capital cost among companies. In terms of independent variables, the mean value of ESOP_dummy is 0.146 , indicating that, in China's Shanghai and Shenzhen A-share markets from 2014 to 2018 , only $14.6 \%$ of listed companies have implemented ESOPs, which reflects that ESOP in the new era in China is now at the pilot stage and only a small proportion of listed companies are willing to try the new equity incentive form (i.e., employee stock ownership plan).

Table 2 reports the descriptive statistics of research variables for the ESOP sample and the non-ESOP sample. In terms of dependent variable, the cost of equity capital of companies implementing ESOPs (0.101) is significantly lower than that of companies not implementing ESOPs (0.108), which preliminarily supports Hypothesis 1, indicating that the implementation of ESOP helps to reduce the cost of equity capital of enterprises. In terms of firm characteristic variables, compared with companies not implementing ESOPs, companies implementing ESOPs have smaller scale, higher growth, lower operating risks, and lower stock liquidity, indicating that companies with smaller scale, higher growth, lower operating risks, or lower stock liquidity are more likely to choose to implement ESOPs. In terms of governance structure variables, compared with companies not implementing ESOPs, companies implementing ESOPs have a smaller board of directors and lower ownership concentration, indicating that companies with a smaller board of directors or more dispersed ownership are more likely to choose to implement ESOPs

Table 3 reports the descriptive statistics of the ESOP contract element variables. It can be seen that 492 companies of the whole sample have implemented EOSPs. The mean value of ESOP_fund is 0.740 , indicating that, in companies implementing ESOPs, 74\% of them solve the funds needed for ESOPs by employee compensation and self-raised funds, which reflects that the funding sources of ESOPs in the new era in China is given priority to employee's own funds and employees involved in the ESOPs need to bear high risk. The mean value of ESOP_stock is 0.720 , indicating that, in companies implementing ESOPs, $72 \%$ of them solve the stock needed for ESOPs by buying shares on the secondary market, which reflects that the stock sources of ESOPs in the new era in China is given priority to the secondary market 
TABLE 1: Descriptive statistics of research variables for the full sample.

\begin{tabular}{|c|c|c|c|c|c|}
\hline Variable & $N$ & Mean & Standard error & Min & $\operatorname{Max}$ \\
\hline $\mathrm{COE}$ & 3360 & 0.113 & 0.038 & 0.000 & 0.536 \\
\hline ESOP_dummy & 3360 & 0.146 & 0.354 & 0.000 & 1.000 \\
\hline Growth & 3360 & 0.178 & 0.299 & -0.304 & 1.351 \\
\hline Board & 3360 & 0.938 & 0.088 & 0.477 & 1.255 \\
\hline ROA & 3360 & 0.074 & 0.061 & -0.542 & 0.672 \\
\hline Lev & 3360 & 0.469 & 0.194 & 0.017 & 1.104 \\
\hline Shr1 & 3360 & 0.360 & 0.154 & 0.036 & 0.864 \\
\hline Size & 3360 & 10.080 & 0.607 & 8.294 & 12.390 \\
\hline Liquidity & 3360 & 1.203 & 0.907 & 0.015 & 7.314 \\
\hline Orisk & 3360 & 0.438 & 0.209 & 0.000 & 0.948 \\
\hline
\end{tabular}

TABle 2: Descriptive statistics of research variables for the grouping sample.

\begin{tabular}{|c|c|c|c|c|c|c|c|c|}
\hline \multirow{2}{*}{ Variable } & \multicolumn{3}{|c|}{ (1) ESOP_dummy $=0$} & \multicolumn{3}{|c|}{ (2) ESOP_dummy $=1$} & \multicolumn{2}{|c|}{ Differences $=(2)-(1)$} \\
\hline & $\mathrm{N}$ & Mean & S.D. & $\mathrm{N}$ & Mean & S.D. & Mean dif. & $t$ value \\
\hline $\mathrm{COE}$ & 2868 & 0.108 & 0.038 & 492 & 0.101 & 0.039 & $-0.007^{* * *}$ & 4.321 \\
\hline Growth & 2868 & 0.170 & 0.302 & 492 & 0.219 & 0.279 & $0.049^{* * *}$ & -3.348 \\
\hline Board & 2868 & 0.942 & 0.091 & 492 & 0.920 & 0.072 & $-0.021^{* * *}$ & 4.963 \\
\hline ROA & 2868 & 0.074 & 0.063 & 492 & 0.075 & 0.049 & 0.001 & -0.129 \\
\hline Lev & 2868 & 0.471 & 0.195 & 492 & 0.454 & 0.190 & $-0.017^{*}$ & 1.846 \\
\hline Shr1 & 2868 & 0.367 & 0.156 & 492 & 0.319 & 0.134 & $-0.048^{* * *}$ & 6.487 \\
\hline Size & 2868 & 10.090 & 0.620 & 492 & 10.02 & 0.527 & $-0.076^{* *}$ & 2.567 \\
\hline Liquidity & 2868 & 1.226 & 0.924 & 492 & 1.071 & 0.785 & $-0.155^{* * *}$ & 3.511 \\
\hline Orisk & 2868 & 0.443 & 0.214 & 492 & 0.414 & 0.173 & $-0.029^{* * *}$ & 2.822 \\
\hline
\end{tabular}

Note. The symbols ${ }^{* * *},{ }^{* *}$, and ${ }^{*}$ indicate significance at the $1 \%, 5 \%$, and $10 \%$ levels, respectively.

TABle 3: Descriptive statistics for the contract elements of ESOP.

\begin{tabular}{|c|c|c|c|c|c|}
\hline Variable name & $\mathrm{N}$ & Mean & Standard error & Min & Max \\
\hline ESOP_fund & 492 & 0.740 & 0.360 & 0 & 1 \\
\hline ESOP_stock & 492 & 0.720 & 0.450 & 0 & 1 \\
\hline ESOP_exepurchase & 492 & 0.191 & 0.194 & 0 & 1 \\
\hline ESOP_lockup & 492 & 1.538 & 0.906 & 0 & 3 \\
\hline
\end{tabular}

purchase and employees participated in the ESOPs need to pay high cost. The mean value of ESOP_exepurchase is 0.191 , indicating that executives subscribe $19.1 \%$ of the shares involved in the ESOPs on average, which reflects that ESOPs in the new era in China mainly targets ordinary employees. The mean value of ESOP_lockup is 1.538, indicating that the average lockup period of ESOPs is less than 2 years, which reflects the short effective incentive period of ESOPs in the new era in China.

\subsection{Regression Analysis}

5.2.1. The Effect of the Implementation of ESOP on the Cost of Equity Capital. (1) Basic Hypothesis Test. In order to test Hypothesis 1, we use the full sample to estimate Model (2), and the results are shown in the first column of Table 4 . The coefficient of ESOP_dummy is -0.004 and significant at the $1 \%$ level, indicating that the implementation of ESOP is significantly negatively correlated with the cost of equity capital, supporting Hypothesis 1 that the implementation of
ESOP reduces the cost of equity capital of enterprises. For companies implementing ESOPs, executive ownership can alleviate the agency conflicts between shareholders and executives and make executives pay more attention to the long-term development of the company. Meanwhile, employee ownership can enhance employees' sense of ownership and responsibility, improve their enthusiasm for work, and thus improve the company's performance. In sum, the implementation of ESOP can stimulate executives and employees at the same time, reduce the conflicts of interest among shareholders, executives, and employees, and thus reduce the cost of equity capital of enterprises.

(2) Heterogeneity Analysis. In order to test Hypothesis 2, we firstly divide the full sample into state-owned companies and non-state-owned companies based on the categorical variable of ownership nature (SOE) and then use the stateowned subsample and the non-state-owned subsample to estimate Model (2), respectively. The results are shown in the second and third columns of Table 4 . The results show that, in non-state-owned enterprises, the implementation of ESOP is significantly negatively correlated with the cost of 
TABLE 4: Regression results: The impact of ESOP implementation on the cost of equity capital.

\begin{tabular}{lccccc}
\hline \multirow{2}{*}{ Variable } & $\begin{array}{c}\text { Hypothesis 1 } \\
\text { Full sample }\end{array}$ & \multicolumn{2}{c}{ Sypothesis 2 } & \multicolumn{2}{c}{ Hypothesis 3 } \\
& State-owned enterprises & Non-state-owned enterprises & Large enterprises & Small enterprises \\
\hline ESOP_dummy & $-0.004^{* * *}(-2.95)$ & $0.002(0.36)$ & $-0.004^{* *}(-2.54)$ & $-0.002(-0.97)$ & $-0.004^{* * *}(-2.68)$ \\
Growth & $-0.003^{* *}(-2.56)$ & $-0.003^{*}(-1.66)$ & $-0.003^{* *}(-2.00)$ & $-0.004^{* * *}(-2.60)$ & $-0.001(-0.89)$ \\
Board & $-0.005(-1.64)$ & $-0.008(-1.57)$ & $-0.005(-1.30)$ & $-0.002(-0.43)$ & $-0.009^{* *}(-2.13)$ \\
ROA & $-0.147^{* * *}(-10.27)$ & $-0.084^{* * *}(-3.14)$ & $-0.162^{* * *}(-9.69)$ & $-0.185^{* * *}(-7.31)$ & $-0.124^{* * * *}(-7.33)$ \\
Lev & $0.019^{* * *}(4.67)$ & $0.036^{* * *}(4.93)$ & $0.009^{*}(1.87)$ & $0.018^{* * *}(2.62)$ & $0.013^{* *}(2.57)$ \\
Shr1 & $0.024^{* * *}(4.82)$ & $0.038^{* * *}(4.29)$ & $0.020^{* * *}(3.32)$ & $0.024^{* * *}(3.24)$ & $0.022^{* * *}(3.42)$ \\
Size & $0.007^{* * *}(9.76)$ & $0.006^{* * *}(5.99)$ & $0.007^{* * *}(7.29)$ & $0.006^{* * *}(5.79)$ & $0.002(1.39)$ \\
Liquidity & $-0.001^{* * *}(-3.96)$ & $-0.003^{* *}(-5.31)$ & $-0.001^{*}(-1.90)$ & $-0.001^{* *}(-1.76)$ & $-0.001^{* * *}(-3.39)$ \\
Orisk & $0.036^{* * *}(8.44)$ & $0.056^{* * *}(8.23)$ & $0.021^{* * *}(3.86)$ & $0.051^{* * *}(8.29)$ & $0.015^{* * *}(2.59)$ \\
Constant & $-0.020(-1.24)$ & $-0.019(-0.75)$ & $-0.016(-0.71)$ & $-0.036(-1.34)$ & $0.104^{* * *}(3.12)$ \\
Industry FE & Controlled & Controlled & Controlled & Controlled & Controlled \\
Year FE & Controlled & Controlled & Controlled & Controlled & Controlled \\
$N$ & 3360 & 1563 & 1797 & 1680 & 1680 \\
Adj. $R$-sq & 0.143 & 0.146 & 0.158 & 0.122 & 0.151 \\
\hline
\end{tabular}

Notes: the numbers in parentheses are $t$ values and the numbers out of parentheses are regression coefficients. The symbols ${ }^{* * *}$, ${ }^{* *}$, and ${ }^{*}$ indicate significance at $1 \%, 5 \%$, and $10 \%$ levels, respectively.

equity capital at the $5 \%$ level (coefficient $=-0.004, p<0.05$ ), while there is no significant relationship between ESOP implementation and the cost of equity capital in state-owned enterprises (coefficient $=0.002, p>0.1$ ). That is, the negative correlation between ESOP implementation and the cost of equity capital exists in non-state-owned enterprises, but does not exist in state-owned enterprises, which supports Hypothesis 2. This suggests that the reduction effect of ESOP implementation on the cost of equity capital is affected by the firm's ownership nature. Compared with state-owned enterprises, non-state-owned enterprises are less affected by government regulation and more by market competition. Since non-state-owned enterprises are responsible for their own risks and profits and losses, executives and shareholders will pay more attention to business performance, so that executives will pay more attention to the long-term development of the enterprise, and shareholders will improve their supervisions. Therefore, the implementation of ESOP in non-state-owned enterprises with more perfect internal and external governance environment can reduce the cost of equity capital.

In order to test Hypothesis 3, we firstly divide the full sample into large companies and small companies based on the categorical variable of firm size (Large), and then use the large enterprise subsample and the small enterprise subsample to estimate Model (2), respectively. The results are shown in the fourth and fifth columns of Table 4 . The results show that, in small enterprises, the implementation of ESOP is significantly negatively correlated with the cost of equity capital at the $1 \%$ level (coefficient $=-0.004, p<0.01$ ), while there is no significant relationship between ESOP implementation and the cost of equity capital in large enterprises (coefficient $=-0.002, p>0.1$ ). In other words, the negative correlation between ESOP implementation and the cost of equity capital exists in small enterprises, but does not exist in large enterprises, which supports Hypothesis 3. This indicates that the reduction effect of ESOP implementation on the cost of equity capital is also affected by the firm size. Compared with large enterprises, small enterprises have more severe financing constrains and less free-riding problems, which enhances the reduction effect of ESOP on the cost of equity capital.

In addition, the regression results of control variables show that the cost of equity capital increases with firm size (Size), but decreases with firm growth (Growth). Both the asset-liability ratio (Lev) and the non-current asset ratio (Orisk) are positively correlated with the cost of equity capital, indicating that the higher the company's financial risk and operational risk, the higher the minimum rate of return required by investors. Both profitability (ROA) and stock liquidity (Liquidity) are negatively correlated with the cost of equity capital, indicating that the higher the profitability and stock liquidity, the lower the cost of equity capital of enterprises. The cost of equity capital is negatively associated with the size of the board (Board) only in small enterprises, but positively associated with the ownership concentration (Shr1) in all scenarios, indicating that the positive effect of board size on the cost of equity capital is pronounced in small companies, and that China's concentrated equity increases companies' equity financing cost.

5.2.2. The Effect of the Contract Design of ESOP on the Cost of Equity Capital. In order to further examine whether the effect of ESOP on the cost of equity capital varies with the contract design of the plan, we use sample companies implementing ESOPs to estimate Model (3), Model (4), Model (5), and Model (6), respectively. The results are shown in Table 5.

Model (3) tests the effect of the funding sources of ESOP on the cost of equity capital. The result shows that the coefficient of ESOP_fund (-0.011) is significantly negative at the $5 \%$ level, indicating that ESOPs funded by employee compensation and self-raised funds are negatively correlated with the cost of equity capital, which supports Hypothesis 4 . This suggests that compared with other sources of funding, companies implementing ESOPs with employee's own funds have lower cost of equity capital. When employees 
TABLE 5: Regression results: the impact of contract elements of ESOP on the cost of equity capital.

\begin{tabular}{|c|c|c|c|c|}
\hline Variable & Model (3) & Model (4) & Model (5) & Model (6) \\
\hline ESOP_fund & $\begin{array}{c}-0.011^{* *} \\
(-2.40)\end{array}$ & & & \\
\hline ESOP_stock & & $\begin{array}{c}0.009^{* *} \\
(2.40)\end{array}$ & & \\
\hline ESOP_exepurchase & & & $\begin{array}{c}-0.022^{* *} \\
(-2.41)\end{array}$ & \\
\hline ESOP_lockup & & & & $\begin{array}{c}-0.005^{* * *} \\
(-2.72)\end{array}$ \\
\hline Growth & $\begin{array}{c}-0.011^{*} \\
(-1.81)\end{array}$ & $\begin{array}{c}-0.012^{*} \\
(-1.95)\end{array}$ & $\begin{array}{c}-0.011^{*} \\
(-1.74)\end{array}$ & $\begin{array}{c}-0.012^{* *} \\
(-2.02)\end{array}$ \\
\hline Board & $\begin{array}{l}-0.004 \\
(-0.17)\end{array}$ & $\begin{array}{l}0.003 \\
(0.12)\end{array}$ & $\begin{array}{l}0.008 \\
(0.33)\end{array}$ & $\begin{array}{c}0.001 \\
(0.04)\end{array}$ \\
\hline ROA & $\begin{array}{l}-0.013 \\
(-0.32)\end{array}$ & $\begin{array}{l}-0.040 \\
(-1.24)\end{array}$ & $\begin{array}{l}-0.017 \\
(-0.53)\end{array}$ & $\begin{array}{l}-0.033 \\
(-1.04)\end{array}$ \\
\hline Lev & $\begin{array}{c}0.042^{* * *} \\
(3.48)\end{array}$ & $\begin{array}{c}0.035^{* * *} \\
(2.96)\end{array}$ & $\begin{array}{c}0.045^{* * *} \\
(3.75)\end{array}$ & $\begin{array}{c}0.037^{* * *} \\
(3.12)\end{array}$ \\
\hline Shr1 & $\begin{array}{c}0.043^{* * *} \\
(3.00)\end{array}$ & $\begin{array}{c}0.045^{* * *} \\
(3.14)\end{array}$ & $\begin{array}{c}0.043^{* * *} \\
(2.88)\end{array}$ & $\begin{array}{c}0.046^{* * *} \\
(3.19)\end{array}$ \\
\hline Size & $\begin{array}{l}0.005 \\
(1.22)\end{array}$ & $\begin{array}{c}0.008^{*} \\
(1.92)\end{array}$ & $\begin{array}{l}0.004 \\
(0.88)\end{array}$ & $\begin{array}{c}0.008^{*} \\
(1.77)\end{array}$ \\
\hline Liquidity & $\begin{array}{c}-0.009^{* * *} \\
(-4.08)\end{array}$ & $\begin{array}{c}-0.009^{* * *} \\
(-4.03)\end{array}$ & $\begin{array}{c}-0.010^{* * *} \\
(-4.24)\end{array}$ & $\begin{array}{c}-0.009^{* * *} \\
(-4.15)\end{array}$ \\
\hline Orisk & $\begin{array}{c}0.012 \\
(0.93)\end{array}$ & $\begin{array}{c}0.010 \\
(0.92)\end{array}$ & $\begin{array}{c}0.010 \\
(0.88)\end{array}$ & $\begin{array}{l}0.009 \\
(0.83)\end{array}$ \\
\hline Constant & $\begin{array}{l}0.079 \\
(1.63)\end{array}$ & $\begin{array}{l}0.032 \\
(0.69)\end{array}$ & $\begin{array}{c}0.075^{*} \\
(1.66)\end{array}$ & $\begin{array}{l}0.053 \\
(1.18)\end{array}$ \\
\hline Industry FE & Controlled & Controlled & Controlled & Controlled \\
\hline Year FE & Controlled & Controlled & Controlled & Controlled \\
\hline$N$ & 492 & 492 & 492 & 492 \\
\hline Adj. $R$-sq & 0.177 & 0.176 & 0.177 & 0.178 \\
\hline
\end{tabular}

Notes: the numbers in parentheses are $t$ values and the numbers out of parentheses are regression coefficients. The symbols ${ }^{* * *},{ }^{* *}$, and ${ }^{*}$ indicate significance at $1 \%, 5 \%$, and $10 \%$ levels, respectively.

participate in ESOPs with their own funds, their personal wealth is linked to the company's stock price, encouraging them to pay more efforts to achieve the improvement of the company's performance, thus reducing the cost of equity financing.

Model (4) tests the effect of the stock sources of ESOP on the cost of equity capital. The result shows that the coefficient of ESOP_stock (0.009) is significantly positive at the 5\% level, indicating that ESOPs implemented by buying shares on the secondary market are positively associated with the cost of equity capital, supporting Hypothesis 5. It suggests that compared with other sources of stock, companies implementing ESOPs by purchasing shares on the secondary market have higher cost of equity capital. Compared with other sources of stock, the cost of stock purchases on the secondary market is relatively higher, so the future holding yield is relatively lower, which will weaken the incentive effect of ESOP and increase the cost of equity capital.

Model (5) tests the effect of the executive subscription ratio in ESOP on the cost of equity capital. The result shows that the coefficient of ESOP_exepurchase $(-0.022)$ is significantly negative at the $5 \%$ level, indicating that the executive subscription ratio in ESOP is negative associated with the cost of equity capital, which supports Hypothesis 6 . It suggests that the higher the proportion of executive subscription in the ESOP, the lower the cost of equity capital of the enterprise. Increasing the executive subscription ratio in ESOP can not only ease the agency conflicts between executives and shareholders but also transmit the positive signal of the company's future performance to the investors, thus reducing the cost of equity capital of the enterprise.

Model (6) tests the effect of the lockup period of ESOP on the cost of equity capital. The result shows that the coefficient of ESOP_lockup (-0.005) is significantly negative at the $1 \%$ level, indicating that the lockup period of ESOP is negatively associated with the cost of equity capital, supporting Hypothesis 7. It suggests that the longer the lockup period of ESOP, the lower the cost of equity capital of the enterprise. The setting of lockup period effectively binds the interests of employees and the company, thus alleviating the agency conflicts between internal employees and external shareholders and reducing the cost of equity capital of the enterprise.

In sum, the results in Table 5 indicate that the impact of ESOP on the cost of equity capital is affected by the contract design of ESOP. 


\subsection{Endogeneity Tests}

5.3.1. Lagged Explanatory Variables. The implementation of ESOP is negatively correlated with the cost of equity capital, which can be explained as the implementation of ESOP reduces the equity capital cost of the enterprise and can also be explained as enterprises with lower equity capital cost are more likely to implement ESOPs. In order to address the endogenous problem caused by mutual causation between ESOP implementation and the cost of equity capital, this paper replaces the cost of equity capital in year $t$ with the cost of equity capital in year $t+1$ and re-estimate Model (2). The results are shown in the first and second columns of Table 6 . The results show that, after using the cost of equity capital in year $t+1$ as the dependent variable in Model (2), the implementation of ESOP is still significantly negatively correlated with the cost of equity capital (coefficient $=-0.003, \quad p<0.05$ ), which further supports Hypothesis 1, thus eliminating the explanation that enterprises with lower equity capital cost are more likely to implement ESOPs.

5.3.2. Propensity Score Matching Estimation. The implementation of ESOP is an endogenous decision of the company, and there may be sample self-selection bias, that is, the differences in the cost of equity capital between the companies that implement ESOPs and the companies that do not implement ESOPs are not caused by the implementation itself, but by the characteristic differences in the two types of companies. In order to address the endogeneity problem caused by sample self-selection bias, this paper uses the propensity score matching (PSM) method to control the characteristic differences between the two types of companies.

In the first step, with the implementation of ESOP as the explained variable and the control variables in Model (2) as the explanatory variables, the logit model is used to estimate the probability of implementing ESOP for each sample, and the probability is taken as the propensity score. In the second step, the $1: 1$ nearest lead matching is used to match each company that implement ESOP with a company that does not implement ESOP with the closest propensity score. The third step is to conduct balance test on matching results (see Table 7). The results show that, before matching, there are significant differences between the samples implementing ESOPs and those not implementing ESOPs in terms of company characteristics, but after matching, there are no significant differences between the two types of samples in terms of company characteristics, indicating that the matching result is good. Finally, regression estimation is performed on Model (2) based on the matched samples, and the results are shown in the third and fourth columns of Table 6 . The results show that, after controlling for sample self-selection bias, ESOP implementation is still significantly negatively correlated with the cost of equity capital (coefficient $=-0.006, p<0.05$ ), which further supports the main research conclusions of this paper.
5.3.3. Difference-in-Differences Estimation. In order to further address the endogeneity problem caused by missing variables and considering the different starting years of ESOP implementation in each treatment sample, the paper constructs the following time-varying difference-in-differences (DID) model:

$$
\mathrm{COE}_{i, t}=\alpha_{0}+\alpha_{1} \text { ESOP_dummy }_{i, t}+\text { Controls }_{i, t}+\mu_{i}+\nu_{t}+\varepsilon_{i, t} \text {, }
$$

where $\mathrm{COE}_{i, t}$ is the cost of equity capital that varies with time and individuals, ESOP_dummy ${ }_{i, t}$ is the implementation of ESOP that varies with time and individuals, Controls $s_{i, t}$ is the control variables that varies with time and individuals (the same control variables as in Model (2)), $\mu_{i}$ is individual-fixed effect, and $v_{t}$ is time-fixed effect.

Based on the PSM matched samples, this paper constructs unbalanced panel data of sample firms, and estimates Model (7) using bidirectional fixed effects. The results are shown in the fifth and sixth columns of Table 6. In addition, before estimating Model (7), this paper calculates the mean values of the treatment group and control group in the four years before and after implementing ESOP and plotted in Figure 2. The figure shows that, in the four years before implementing ESOP, the change trends of equity capital cost in the treatment group and the control group are very similar, and there are no significant differences among different years. It indicates that the parallel trend hypothesis of DID estimation is satisfied. Most of all, the estimation results of time-varying DID model show that after excluding the influences of individual differences and time trends, the implementation of ESOP is still significantly negatively correlated with the cost of equity capital (coefficient $=-0.018, p<0.05$ ), which further supports the main research conclusions of this paper.

\subsection{Robustness Tests}

5.4.1. Replace the Measurement Model of the Cost of Equity Capital. At present, there are many models to measure the cost of equity capital, including ex ante measure models and ex post measure models, among which PEG model belongs to ex ante measure model. In order to improve the reliability of empirical results, this paper further uses an ex post measure model widely used in academia, namely, capital asset pricing model (CAPM), to re-estimate the cost of equity capital of enterprises. The CAPM is expressed as follows:

$$
\mathrm{COE}_{i}=R_{f}+\beta *\left(R_{m}-R_{f}\right),
$$

where $R_{f}$ is the risk-free return rate, usually measured by the annual interest rate of treasury bonds; $\beta$ represents the systemic risk of a stock; $R_{m}$ represents the market rate of return, representing the average annual rate of return of individual shares of all stocks in the market.

After the cost of equity capital is estimated by Model (8), it is taken as the dependent variable of Model (2). On this basis, Model (2) is re-estimated, and the results are shown in 
TABLE 6: Endogeneity test results.

\begin{tabular}{|c|c|c|c|c|c|c|}
\hline \multirow{2}{*}{ Variable } & \multicolumn{2}{|c|}{ (1) dependent $=\mathrm{COE}_{t+1}$} & \multicolumn{2}{|c|}{ (2) PSM estimation } & \multicolumn{2}{|c|}{ (3) DID estimation } \\
\hline & Coefficient & $t$ value & Coefficient & $t$ value & Coefficient & $t$ value \\
\hline ESOP_dummy & $-0.003^{* *}$ & -2.00 & $-0.006^{* *}$ & -2.54 & $-0.018^{* *}$ & -2.57 \\
\hline Growth & 0.0004 & 0.25 & -0.001 & -0.35 & $-0.006^{* * *}$ & -4.71 \\
\hline Board & $-0.007^{*}$ & -1.75 & -0.008 & -1.25 & $0.014^{*}$ & 1.80 \\
\hline $\mathrm{ROA}$ & $-0.065^{* * *}$ & -3.59 & $-1.734^{* * *}$ & -6.31 & $-0.227^{* * *}$ & -9.11 \\
\hline Lev & $0.028^{* * *}$ & 5.27 & 0.004 & 0.41 & -0.005 & -0.60 \\
\hline Shr1 & 0.010 & 1.47 & 0.014 & 1.33 & $0.052^{* * *}$ & 2.97 \\
\hline Size & $0.007^{* * *}$ & 8.23 & $0.007^{* * *}$ & 4.84 & $0.014^{* * *}$ & 4.99 \\
\hline Liquidity & -0.001 & -1.47 & -0.001 & -1.62 & $-0.002^{* * *}$ & -5.16 \\
\hline Orisk & $0.040^{* * *}$ & 7.22 & $0.027^{* * *}$ & 2.99 & 0.007 & 0.55 \\
\hline Constant & $-0.054^{* *}$ & -2.42 & -0.017 & -0.48 & $-0.239^{* * *}$ & -3.38 \\
\hline Industry FE & \multicolumn{2}{|c|}{ Controlled } & \multicolumn{2}{|c|}{ Controlled } & \multicolumn{2}{|c|}{ Controlled } \\
\hline Year FE & \multicolumn{2}{|c|}{ Controlled } & \multicolumn{2}{|c|}{ Controlled } & \multicolumn{2}{|c|}{ Controlled } \\
\hline Individual FE & \multicolumn{2}{|c|}{ No } & \multicolumn{2}{|c|}{ No } & \multicolumn{2}{|c|}{ Yes } \\
\hline$F$-value & \multicolumn{2}{|c|}{$30.98^{* * *}$} & \multicolumn{2}{|c|}{$15.73^{* * *}$} & \multicolumn{2}{|c|}{$27.14^{* * *}$} \\
\hline Adj. $R$-sq & \multicolumn{2}{|c|}{0.132} & \multicolumn{2}{|c|}{0.176} & \multicolumn{2}{|c|}{0.152} \\
\hline
\end{tabular}

Note. The symbols ${ }^{* * *},{ }^{* *}$, and ${ }^{*}$ indicate significance at $1 \%, 5 \%$, and $10 \%$ levels, respectively.

TABLE 7: The balancing test results of PSM.

\begin{tabular}{|c|c|c|c|c|c|c|c|}
\hline \multirow{2}{*}{ Variable } & \multirow{2}{*}{ Sample } & \multicolumn{2}{|c|}{ Mean } & \multirow{2}{*}{$\%$ bias } & \multirow{2}{*}{$\%$ reduce $\mid$ bias $\mid$} & \multicolumn{2}{|c|}{$t$ test } \\
\hline & & Treated & Control & & & $t$ value & $p$ value \\
\hline \multirow{2}{*}{ Size } & Unmatched & 22.457 & 22.513 & -4.3 & & -1.49 & 0.136 \\
\hline & Matched & 22.457 & 22.459 & -0.2 & 95.8 & -0.05 & 0.956 \\
\hline \multirow{2}{*}{ Lev } & Unmatched & 0.41742 & 0.43442 & -8.5 & & $-3.05^{* * *}$ & 0.002 \\
\hline & Matched & 0.41752 & 0.41742 & 0.1 & 99.4 & 0.02 & 0.988 \\
\hline \multirow{2}{*}{ ROA } & Unmatched & 0.04238 & 0.04251 & -0.3 & & -0.09 & 0.927 \\
\hline & Matched & 0.04234 & 0.0417 & 1.3 & -413.3 & 0.36 & 0.719 \\
\hline \multirow{2}{*}{ Growth } & Unmatched & 0.26942 & 0.22541 & 8.8 & & $3.10^{* * *}$ & 0.002 \\
\hline & Matched & 0.26921 & 0.3037 & -6.9 & 21.6 & $-1.86^{*}$ & 0.063 \\
\hline \multirow{2}{*}{ Orisk } & Unmatched & 0.21931 & 0.26623 & -27.7 & & $-9.56^{* * *}$ & $\leq 0.01$ \\
\hline & Matched & 0.21944 & 0.21966 & -0.1 & 99.5 & -0.04 & 0.968 \\
\hline \multirow{2}{*}{ Liquidity } & Unmatched & 3.2368 & 3.6282 & -15.7 & & $-5.57^{* * *}$ & $\leq 0.01$ \\
\hline & Matched & 3.2396 & 3.3005 & -2.4 & 84.4 & -0.73 & 0.465 \\
\hline \multirow{2}{*}{ Shr1 } & Unmatched & 0.3165 & 0.35548 & -27.8 & & $-9.73^{* * *}$ & $\leq 0.01$ \\
\hline & Matched & 0.31666 & 0.31213 & 3.2 & 88.4 & 0.98 & 0.326 \\
\hline \multirow{2}{*}{ Board } & Unmatched & 2.095 & 2.1448 & -24.8 & & $-9.01^{* * *}$ & $\leq 0.01$ \\
\hline & Matched & 2.0949 & 2.0872 & 3.8 & 84.6 & 1.09 & 0.277 \\
\hline Sample & Ps R-sq & LR chi-sq & $p>$ chi-sq & Mean bias & Median bias & B & $\mathrm{R}$ \\
\hline Unmatched & 0.084 & 737.78 & $\leq 0.01$ & 22.7 & 24.8 & 78.0 & 0.57 \\
\hline Matched & 0.002 & 7.20 & 0.783 & 1.8 & 1.3 & 9.3 & 0.70 \\
\hline
\end{tabular}

Note. The symbols ${ }^{* * *},{ }^{* *}$, and ${ }^{*}$ indicate significance at $1 \%, 5 \%$, and $10 \%$ levels, respectively.

the first column of Table 8 . As can be seen from the table, after replacing the measurement model of equity capital cost, the implementation of ESOP is still significantly negatively correlated with the cost of equity capital at the $1 \%$ level (coefficient $=-0.102, \quad p<0.01$ ), further supporting $\mathrm{Hy}-$ pothesis 1 .

5.4.2. Replace the Measurement Method of Firm Size. In addition to the total assets can reflect the size of the enterprise, the total number of employees can also reflect the size of the enterprise. Thus, this paper further replaces the total assets with the total number of employees to measure the firm size. On this basis, we firstly divide the full sample into small enterprises and large enterprises based on the total number of employees and then use the two subsamples to estimate Model (2), respectively. The results are shown in the second and third columns of Table 8 . It suggests that, after replacing the measurement method of firm size, the negative association between ESOP implementation and the cost of equity capital still exists in small enterprises, and not exists in large enterprises, which further supports Hypothesis 3.

5.4.3. Adjust the Test Method of Moderating Effect. The grouping regression method was used to test the moderating effects of ownship nature and firm size (i.e. Hypothesis 2 and Hypothesis 3) above, but this method could not directly compare the coefficients of the two subgroups after grouping regression and greatly reduced the number of regression 


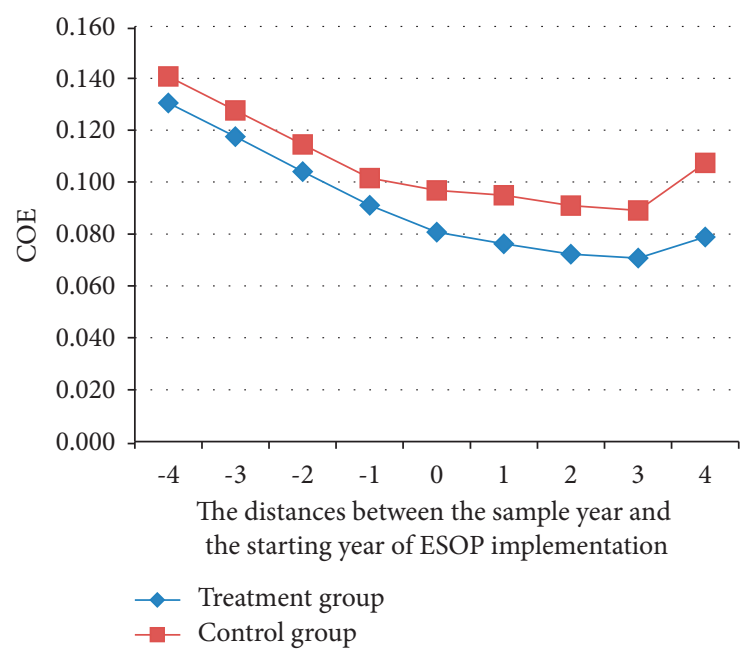

FIGURE 2: The change trends of equity capital cost in the treatment group and the control group.

TABLE 8: Robustness test results.

\begin{tabular}{|c|c|c|c|c|c|}
\hline \multirow[t]{2}{*}{ Variable } & \multirow{2}{*}{$\begin{array}{l}\text { (1) Replace the measurement model of } \\
\text { COE }\end{array}$} & \multicolumn{2}{|c|}{$\begin{array}{l}\text { (2) Replace the measurement } \\
\text { method of firm size }\end{array}$} & \multicolumn{2}{|c|}{$\begin{array}{l}\text { (3) Adjust the test method of } \\
\text { moderating effect }\end{array}$} \\
\hline & & Large enterprises & Small enterprises & Hypothesis 2 & Hypothesis 3 \\
\hline ESOP_dummy & $-0.102^{* * *}(-3.88)$ & $-0.001(-0.65)$ & $-0.005^{* *}(-2.26)$ & $-0.009^{* * *}(-2.58)$ & $-0.043^{*}(-1.82)$ \\
\hline SOE & & & & $-0.013^{* * *}(-8.84)$ & \\
\hline ESOP_dummy*SOE & & & & $0.011^{* *}(1.96)$ & \\
\hline ESOP_dummy*Size & & & & & $0.002^{*}(1.65)$ \\
\hline Size & $0.064^{* * *}(3.14)$ & $0.008^{* * *}(7.00)$ & $0.006^{* * *}(5.26)$ & $0.009^{* * *}(6.02)$ & $0.006^{* * *}(8.87)$ \\
\hline Growth & $-0.059^{* *}(-2.20)$ & $-0.003^{*}(-1.79)$ & $-0.003^{*}(-1.95)$ & $-0.004^{* * *}(-3.39)$ & $-0.003^{* *}(-2.54)$ \\
\hline Board & $-0.112(-1.05)$ & $-0.003(-0.64)$ & $-0.007(-1.64)$ & $-0.037^{* * *}(-4.98)$ & $-0.005^{*}(-1.65)$ \\
\hline ROA & $-1.458^{* * *}(-8.65)$ & $\begin{array}{c}-0.167^{* * *} \\
(-7.16)\end{array}$ & $\begin{array}{c}-0.125^{* * *} \\
(-6.35)\end{array}$ & $\begin{array}{c}-0.152^{* * *} \\
(-13.64)\end{array}$ & $\begin{array}{c}-0.148^{* * *} \\
(-10.31)\end{array}$ \\
\hline Lev & $0.308^{* * *}(4.80)$ & $0.026^{* * *}(3.57)$ & $0.017^{* * *}(3.29)$ & $0.037^{* * *}(7.90)$ & $0.019^{* * *}(4.60)$ \\
\hline Shr1 & $0.467^{* * *}(7.40)$ & $0.023^{* * *}(3.04)$ & $0.020^{* * *}(2.82)$ & $0.030^{* * *}(6.50)$ & $0.025^{* * *}(4.87)$ \\
\hline Liquidity & $-0.227^{* * *}(-20.65)$ & $\begin{array}{c}-0.001^{* * *} \\
(-2.92)\end{array}$ & $-0.001^{* *}(-1.99)$ & $-0.004^{* * *}(-5.43)$ & $-0.001^{* * *}(-3.96)$ \\
\hline Orisk & $0.049(1.11)$ & $0.057^{* * *}(8.50)$ & $0.018^{* * *}(3.13)$ & $0.027^{* *}(2.23)$ & $0.036^{* * *}(8.48)$ \\
\hline Constant & $0.019(0.09)$ & $-0.057^{* *}(-2.19)$ & $0.005(0.17)$ & $0.048^{* * *}(3.10)$ & $-0.013(-0.77)$ \\
\hline Industry FE & Controlled & Controlled & Controlled & Controlled & Controlled \\
\hline Year FE & Controlled & Controlled & Controlled & Controlled & Controlled \\
\hline$N$ & 3360 & 1680 & 1680 & 3360 & 3360 \\
\hline Adj. $R$-sq & 0.156 & 0.137 & 0.168 & 0.120 & 0.143 \\
\hline
\end{tabular}

Notes: the numbers in parentheses are $t$ values, and the numbers out of parentheses are regression coefficients. The symbols ${ }^{* * *},{ }^{* *}$, and ${ }^{*}$ indicate significance at $1 \%, 5 \%$, and $10 \%$ levels, respectively.

samples. Therefore, this paper further tests Hypothesis 2 by adding an interaction item between ESOP implementation (ESOP_dummy) and ownership nature (SOE) into Model (2) and tests Hypothesis 3 by adding an interaction item between ESOP implementation and firm size (Size) into the model. The results are shown in the fourth and fifth columns of Table 8. As can be seen from the table, the coefficient of ESOP_dummy is significantly negative at the $1 \%$ level, but the interaction term (ESOP_dummy*SOE) is significantly positive at the $5 \%$ level, indicating that state-owned property rights offset the reduction effect of ESOP on the cost of equity capital, further supporting Hypothesis 2. In addition, the interaction term (ESOP_dummy*Size) is significantly positive at the $10 \%$ level, indicating that the reduction effect of ESOP on the cost of equity capital decreases with firm size, which further supports Hypothesis 3.

\section{Conclusion and Discussion}

Since the CSRC issued the Guiding Opinions on June 20, 2014, more and more listed companies have chosen to implement ESOPs. Accordingly, a large number of literatures about ESOP have emerged in Chinese academic circles in recent years, but these literature studies have not paid attention to the relationship between ESOP and the cost of equity capital. Based on this, this paper takes Chinese 
A-share listed companies in Shanghai and Shenzhen Stock Exchanges from 2014 to 2018 as research sample, discusses whether the implementation of ESOP in a new era in China affects the equity capital cost of enterprises, and further examines whether the effect varies with the ownership nature and the size of enterprises. In addition, we also investigate whether the contract design of ESOP affects the cost of equity capital.

This study finds that the implementation of ESOP in Chinese listed companies with equity financing preference can reduce the cost of equity capital, indicating that the employee stock ownership system in the new era in China can help reduce the cost of equity capital of enterprises. This is different from the findings of Aubert et al. [23] and Campa and Kern [24]. This may be because China's employee stock ownership system in the new era is quite different from that of France and the United States. First of all, French companies with more than 50 employees are forced to implement the profit-sharing system, so the phenomenon of employee ownership is relatively common in French-listed companies, and the employee ownership ratio is relatively high. However, Chinese-listed companies implementing ESOPs follow the company's independent decision and the principle of voluntary participation, and the Guiding Opinions regulates that the total number of shares held by the ESOP must not exceed $10 \%$ of the company's total shares and the number of shares held by a single employee shall not exceed $1 \%$ of the company's total shares. Secondly, the ESOPs implemented by American-listed companies are kinds of retirement welfare plans with long-term incentive nature. The stocks held by employees of the company can only be cashed out after their retirements. However, the ESOPs implemented by Chinese-listed companies have definite lockup period and duration, and the stocks held by the ESOP can be sold after the lockup period expires. At present, most of the lockup periods of ESOPs are less than 3 years, and the durations are less than 4 years. In addition, "ESO" discussed by Aubert et al. [23] and Campa and Kern [24] specifically refers to the shareholding ratio of nonexecutive employees, while the incentive objects of ESOPs in the new era in China include both senior executives and ordinary employees, that is, the incentive effect of ESOP includes both senior executive shareholdings and ordinary employees shareholdings. In conclusion, on the premise that the incentive object is wide and the shareholding scale is limited in China, the implementation of employee ownership system can help reduce the cost of equity financing of enterprises.

After further differentiating the property rights and the size of enterprises, we find that the reduction effect of ESOP on the cost of equity capital exists in non-state-owned enterprises and small enterprises, but does not exist in state-owned enterprises and large enterprises. It indicates that the imperfect internal and external governance environment in state-owned enterprises and the more severe free-riding problems in large enterprises counterbalance the reduction effect of ESOP on the cost of equity capital. By examining the relationship between the contract elements of ESOP and the cost of equity capital, we further find that the impact of ESOP on the cost of equity capital varies with the contract design of ESOP. Specifically, compared with other sources of funding, ESOPs implemented by employee compensation and self-raised funds are more conducive to reducing the cost of equity capital. Compared with purchasing stocks on the secondary market, ESOPs implemented by subscribing for nonpublic offering shares or repurchasing the company's own shares by listed companies are more conducive to reducing the cost of equity capital. ESOPs with higher executive subscription ratios or longer lockup periods can help lower the cost of equity capital of enterprises.

This study also has several practical implications. First, the government should attach importance to the implementation of ESOPs, formulate preferential policies of targeted, establish and perfect the laws and regulations of the ESOP, and further promote the enterprises' implementation of ESOPs. Secondly, aimed at the problem of insufficient incentive effect of the ESOP, state-owned enterprises need to raise dong the guardianship supervision of internal management personnel of enterprises, introduce a third-party management agencies to day-to-day management of ESOP, reduce the risk of management control power, reduce the occurrence of employee free-rider problems, make more employees participate in corporate governance, and fundamentally safeguard the investment rights and interests of employees. Finally, according to the relevant provisions in the Guiding Opinions, enterprises need to reasonable design the contract elements of ESOPs, including selecting flexible funding sources and stock sources, allocating subscription ratios between executives and employees reasonably, and setting appropriate lockup periods and durations, so as to exert the maximum utility of human capital.

\section{Data Availability}

The data used to support the findings of this study are available from the corresponding author upon request.

\section{Conflicts of Interest}

The authors declare that they have no conflicts of interest.

\section{Acknowledgments}

This manuscript was supported by the National Natural Science Foundation of China (grant no. 71802044) and the Fundamental Research Funds for the Central Universities of China (grant no. N2006002).

\section{References}

[1] R. Lambert, C. Leuz, and R. E. Verrecchia, "Accounting information, disclosure, and the cost of capital," Journal of Accounting Research, vol. 45, no. 2, pp. 385-420, 2007.

[2] K. Hou, M. A. Van Dijk, and Y. Zhang, "The implied cost of capital: a new approach," Journal of Accounting and Economics, vol. 53, no. 3, pp. 504-526, 2012. 
[3] S. Huang and G. Zhang, "Analysis of equity financing preference of Chinese listed companies," Economic Research Journal, no. 11, pp. 12-20, 2001.

[4] Y. Gao, "The generation and governance of equity financing preference of Chinese listed companies," Business Management Journal, no. 6, pp. 66-71, 2002.

[5] Z. Lu and K. Ye, "Analysis of equity financing preference of Chinese listed companies: is preference for equity financing due to low financing cost?" Economic Research Journal, no. 4, pp. 50-59, 2004.

[6] D. A. Shackelford, "The market for tax benefits," Journal of Accounting and Economics, vol. 14, no. 2, pp. 117-145, 1991.

[7] S. Chaplinsky and G. Niehaus, "The role of ESOPs in takeover contests," The Journal of Finance, vol. 49, no. 4, pp. 1451-1470, 1994.

[8] E. H. Kim and P. Ouimet, "Broad-based employee stock ownership: motives and outcomes," The Journal of Finance, vol. 69, no. 3, pp. 1273-1319, 2014.

[9] L. A. Gordon and J. Pound, "ESOPs and corporate control," Journal of Financial Economics, vol. 27, no. 2, pp. 525-555, 1990.

[10] S. Chang and D. Mayers, "Managerial vote ownership and shareholder wealth," Journal of Financial Economics, vol. 32, no. 1, pp. 103-131, 1992.

[11] M. R. Muhtaseb, "Employee stock ownership plans, common stock wealth effects and stock price variability," Managerial Finance, vol. 23, no. 3, pp. 39-48, 1997.

[12] S. Park and M. H. Song, "Employee stock ownership plans, firm performance, and monitoring by outside blockholders," Financial Management, vol. 24, no. 4, pp. 52-65, 1995.

[13] J. Blasi, M. Conte, and D. Kruse, "Employee stock ownership and corporate performance among public companies," Industrial and Labor Relations Review, vol. 50, no. 1, pp. 60-79, 1996.

[14] R. Meng, X. Ning, X. Zhou, and H. Zhu, "Do ESOPs enhance firm performance? Evidence from China's reform experiment," Journal of Banking \& Finance, vol. 35, no. 6, pp. 1541-1551, 2011.

[15] C. Botosan, "Disclosure level and the cost of equity capital," The Accounting Review, vol. 72, no. 3, pp. 323-349, 1997.

[16] W. R. Gebhardt, C. M. C. Lee, and B. Swaminathan, "Toward an implied cost of capital," Journal of Accounting Research, vol. 39, no. 1, pp. 135-176, 2001.

[17] C. S. Armstrong, J. E. Core, D. J. Taylor, and R. E. Verrecchia, "When does information asymmetry affect the cost of capital?" Journal of Accounting Research, vol. 49, no. 1, 2011.

[18] F. Bova, K. Kolev, J. K. Thomas, and X. F. Zhang, "Nonexecutive employee ownership and corporate risk," The Accounting Review, vol. 90, no. 1, pp. 115-145, 2015.

[19] F. Bova, Y. Dou, and O.-K. Hope, "Employee ownership and firm disclosure," Contemporary Accounting Research, vol. 32, no. 2, pp. 639-673, 2015.

[20] W. Zhang, G. Luo, and Y. Tao, "The shareholder wealth effect of employee stock ownership plan in listed companies," Journal of Beijing Technology and Business University, vol. 31, no. 2, pp. 61-70, 2016.

[21] H. Sheng, L. Hua, and J. Xu, "Operating performance of stateowned enterprises implementing ESOPs," Management World, no. 11, pp. 121-133, 2018.

[22] J. B. Barney, "Employee stock ownership and the cost of equity in Japanese electronics firms," Organization Studies, vol. 11, no. 3, pp. 353-372, 1990.
[23] N. Aubert, A. Kern, and X. Hollandts, "Employee stock ownership and the cost of capital," Research in International Business and Finance, vol. 41, no. 5, pp. 67-78, 2017.

[24] D. Campa and A. Kern, "Employee stock ownership and cost of capital: evidence from the S\&P 500," Journal of Corporate Accounting \& Finance, vol. 31, no. 3, pp. 150-162, 2020.

[25] H.-L. Chen and Y.-S. Huang, "Employee stock ownership and corporate R\&D expenditures: evidence from Taiwan's information-technology industry," Asia Pacific Journal of Management, vol. 23, no. 3, pp. 369-384, 2006.

[26] J. Chen, T. D. King, and M. Wen, "Non-executive ownership and private loan pricing," Journal of Corporate Finance, vol. 64, pp. 1-30, Article ID 101638, 2020.

[27] H. Jung and S. Choi, "The effects of employee stock ownership on stock liquidity: evidence from the Korean market," The North American Journal of Economics and Finance, vol. 58, pp. 1-16, Article ID 101468, 2021.

[28] P. Quimet and G. Tate, "Attention for the inattentive: positive effects of negative financial shocks," Review of Finance, vol. 24, no. 3, pp. 615-646, 2020.

[29] T. Ren, Y. Xiao, H. Yang, and S. Liu, "Employee ownership heterogeneity and firm performance in China," Human Resource Management, vol. 58, no. 6, pp. 621-639, 2019.

[30] H. Xiao, Y. Shi, and A. Varma, "The effects of employee stock ownership plans on career development in a new era," Career Development International, vol. 24, no. 5, pp. 453-474, 2019.

[31] Y. Li, B. Sun, and S. Yu, "Employee stock ownership plan and stock price crash risk," Frontiers of Business Research in China, vol. 13, no. 3, pp. 251-283, 2019.

[32] D. Si, Y. Wang, and D. Kong, "Employee incentives and energy firms' innovation: evidence from China," Energy, vol. 212, pp. 1-11, 2020.

[33] J. Chen, J. Liu, F. Mo, and L. Xu, "The optimal proportion of employee stock in the duopoly completion," Transformations in Business and Economics, vol. 18, no. 3, pp. 512-529, 2019.

[34] J. Chen, H. Tang, and J. Liu, "Duopoly, optimal proportion of state-owned shares and international cross-ownership," Revista de Cercetare şi Intervenţie Socială, vol. 64, pp. 352-365, 2019.

[35] J. Chen, M. Wang, Y. Gao, and Y. Long, "Duopoly, mixed ownership, and the optimal proportion of employee stocks in state-owned enterprises in China," Managerial and Decision Economics, vol. 40, no. 5, pp. 550-558, 2019.

[36] M. C. Jensen and W. H. Meckling, "Theory of the firm: managerial behavior, agency costs and ownership structure," Journal of Financial Economics, vol. 3, no. 4, pp. 305-360, 1976.

[37] H. Meran, "Executive compensation structure, ownership and firm performance," Review of Accounting Studies, vol. 18, no. 4, pp. 1159-1190, 2013.

[38] K. C. W. Chen, Z. Chen, and K. C. J. Wei, "Legal protection of investors, corporate governance, and the cost of equity capital," Journal of Corporate Finance, vol. 15, no. 3, pp. 273-289, 2009.

[39] N. Attig, O. Guedhami, and D. Mishra, "Multiple large shareholders, control contests, and implied cost of equity," Journal of Corporate Finance, vol. 14, no. 5, pp. 721-737, 2008.

[40] Q. Huang, J. Yu, X. Wang, and J. Shao, "Research on China's employee stock ownership system in the new era," China Industrial Economics, no. 7, pp. 5-16, 2014.

[41] D. Czarnitzki and H. Hottenrott, "R\&D investment and financing constraints of small and medium-sized firms," Small Business Economics, vol. 36, no. 1, pp. 65-83, 2011. 
[42] X. Chang, K. Fu, A. Low, and W. Zhang, "Non-executive employee stock options and corporate innovation," Journal of Financial Economics, vol. 115, no. 1, pp. 168-188, 2014.

[43] P. D. Easton, "PE ratios, PEG ratios, and estimating the implied expected rate of return on equity capital," The Accounting Review, vol. 79, no. 1, pp. 73-95, 2004. 